\section{JP Rossouw}

Professor, Edu-HRight

Research Unit, Faculty of

Education, North-West

University, Potchefstroom.

\section{E Mong}

Edu-HRight Research

Unit, Faculty of Education,

North-West University,

Potchefstroom

ISSN 0258-252X (Print)

ISSN 2415-0517 (Online)

DOl: https://dx.doi.

org/10.18820/24150517/ JJS43.12.5

Journal for Juridical

Science

2018:43(2):109-136

\section{(C) Creative Commons} With Attribution (CC-BY)

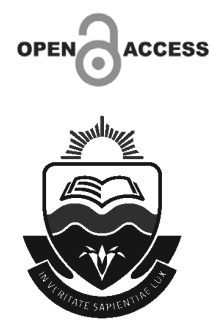

\section{Educator professional} security in public schools over the past decade: A meta-synthesis

\section{Abstract}

It is widely accepted that most of the aspects related to the nature and quality of an education system are closely linked to the positive or negative contribution of the educator in the system. Educators operate in their professional capacity within the South African legal framework and are subject, in their service delivery, to the Constitution of the Republic of South Africa of 1996, labour legislation, the South African Schools Act and other applicable legislation as well as a wide spectrum of common law principles that guide their actions. Educators likewise have to perform their professional duties in a societal environment directly influenced by political decisions and leadership, as well as an education environment that often reflects the societal ills such as corruption and other forms of criminality. This article points out, from both a fundamental rights perspective and a labour law perspective, that educators' right to professional security, which is closely related to their constitutional and labour right to security, is not properly upheld by the relevant authorities. Such lack of professional security adversely influences the quality of their service delivery. The article draws from the findings of a set of postgraduate studies completed over the past decade, all forming part of a central project on educator security. A variety of types of educators, foci and research sites formed the settings for these studies, including beginner educators, early childhood educators, educators who have to cope with serious misconduct by either learners or fellow educators, and educators striving towards creativity. The research intends to reveal deeper insight into educator professional security in South Africa. This is achieved by means of a literature study and a legal analysis, as well as a meta-synthesis of the findings of the set of completed studies. A meta-synthesis is typically conducted when a researcher analyses data sets of completed studies, resulting in an integrated interpretation, which leads to a more comprehensive and deeper understanding of the primary findings. It was found in the studies mentioned that educators seriously lack the required basic knowledge of the law that will enable them to effectively cope with the demands of their profession, in particular regarding the application of legal principles. This lack of expertise creates legal risks and uncertainty among educators, leading to a general experience 
of insecurity. The article concludes with a concise exposition of the deeper insight gained regarding educator professional security. Although no generalisations can be drawn from the qualitative empirical research in these studies, this insight may be of value to those who strive towards educator security for the benefit of an individual, a school, or the public education system.

\section{Problem statement}

South African society has witnessed the growth of its democracy for over two decades, a process characterised by a prominent focus on every citizen's fundamental rights. The lack of acknowledgement of everyone's human rights prior to 1994 ensured that noticeable equality among individuals and groups, characteristic of a true democratic approach, was envisaged for the new dispensation. Social security is protected by sec. 27 of the Bill of Rights, as contained in the Constitution of the Repubic of South Africa 1996, while sec. 12 refers to everyone's "right to freedom and security of the person". Various other provisions in the Bill of Rights are directly or indirectly connected with the concept of security. As will be discussed below, the current government is unable to provide adequate physical or psychological security to its citizens, as portrayed by, inter alia, the high levels of private and state corruption, ${ }^{1}$ self-enrichment, nepotism, and various forms of physical violence in society.

\subsection{Societal environment}

Corruption Watch ${ }^{2}$ defines corruption as "the abuse of public resources or public power for personal gain". In 2017, Anbeek ${ }^{3}$ stated that corruption had been thoroughly established in public administration, and referred to the leadership, at that time, of President Zuma: "The president pays for his villa with taxpayer money, police look the other way for a small fee and teachers give good grades in exchange for sex." She quoted Bongi Mlangeni, communications director at Corruption Watch, who says: "The public has completely lost confidence in the government. Those in power have zero credibility - which is even worse than the financial toll corruption takes." This observation is confirmed by the forced resignation of former President Zuma in February 2018, after surviving 7 unsuccessful motions of no-confidence. Ample proof exists of state capture that necessitated an extensive inquiry, under the leadership of Zondo. ${ }^{4}$

Since President Ramaphosa took over the leadership, many improvements have been witnessed. There is a significant movement

1 See https://www.business-anti-corruption.com/country-profiles/south-africa/.

2 Corruption Watch "Annual report 2016", http://www.corruptionwatch.org.za/ learn-about-corruption/reports/annual-report (accessed on 22 January 2017).

3 Anbeek "Corruption Watch shakes up South Africa", https://www.hivos.org/ corruption-watch-shakes-south-africa (accessed on 21 January 2017).

4 Mashiyane Zondo inquiry and corruption charges pose a twin threat against Zuma, https://mg.co.za/article/2018-09-13-zondo-inquiry-and-corruptioncharges-pose-a-twin-threat-against-zuma (accessed on 25 September 2018). 
away from the "culture of corruption and impunity fostered over the past nine years" ${ }^{\prime 5}$ under the previous President. These initiatives include the investigation into state capture and the removal of leaders associated with the culture of impunity. ${ }^{6}$ In a more stable society, the education system will be enhanced and the security of both educators and learners can be improved. The educational task of the State is to provide quality education within an environment conducive to such education.

\subsection{Education environment}

Despite signs of new hope under the current leadership, the society as described above cannot yet be depicted as a "democratic and open society in which ... every citizen is equally protected by law", and a society "based on democratic values, social justice and fundamental human rights", as envisaged in the preamble of the Constitution. Unfortunately, the education environment reflects elements of such an imperfect society, some of which will now be discussed.

\subsubsection{Education, corruption and politics}

At a United Nations meeting in 2013, former President Zuma referred to the Global Education First Initiative (GEFI): "As a developing country, South Africa firmly believes that the government should take the lead in the provision of education to its people. Whilst much still has to be done, we have made significant progress in making education accessible to all." At the launch of the ANC election manifesto in April 2016, Mr Zuma stated that "... education is the top priority for the African National Congress". ${ }^{8} \mathrm{He}$ added that "corrupt ANC officials, even at municipal level, would be held accountable" and that "the anti-fraud and anti-corruption programmes continue". 9 At the Department of Basic Education (DBE) lekgotla in

5 Tabane Cyril's first 100 days: So much has happened, while so much has remained the same. https://www.news24.com/SouthAfrica/News/cyrilsfirst-100-days-so-much-has-happened-while-so-much-has-remained-thesame-20180527 (accessed on 25 September 2018).

6 Mahlase ANC North West PEC disbanded, Supra Mahumapelo removed as provincial chair, https://mg.co.za/article/2018-08-31-anc-north-west-pecdisbanded-supra-mahumapelo-removed-as-provincial-chair (accessed on 25 September 2018).

7 The Presidency "Remarks by President Jacob Zuma to the UN Secretary General's Global Education First Initiative, High-Level Roundtable, UN Headquarters, New York, United States of America", http://www. thepresidency.gov.za/speeches/remarks-president-jacob-zuma-unsecretary-general\%E2\%80\%99s-global-education-first-initiative $\% 2 \mathrm{C}$-high (accessed on 24 August 2017).

8 Maromo "Education an apex priority for ANC: Zuma", https://www.iol.co.za/ news/politics/education-an-apex-priority-for-anc-zuma-2010577 (accessed on 21 May 2016).

9 Maromo "Education an apex priority for ANC: Zuma", https://www.iol.co.za/news/ politics/education-an-apex-priority-for-anc-zuma-2010577 (accessed on 21 May 2016). 
Centurion, he described education as a primary weapon for economic transformation and "a priority for the government". ${ }^{10}$ These were, however, hollow promises and declarations. In stark contrast to the idealistic picture portrayed by the former President of careful government attention to education, educators are seeking some security in an environment not conducive to excellent teaching. The Corruption Watch 2016 Annual Report ${ }^{11}$ indicates that schools are at the top of the list of hotspots identified during 2015, with a ranking of 16 per cent, in comparison to road housing ( 5 per cent), immigration ( 6 per cent), licensing ( 6 per cent) and traffic ( 7 per cent). Similar to previous years' annual reports, abuse of power accounts for 28 per cent of the corruption reports, with bribery at 24 per cent, and procurement corruption at 17 per cent.

Initiated by the Minister of Basic Education, Mrs Angie Motshekga, the Government has embarked on an investigation of corruption in public education after widespread allegations of selling of educator posts. The Ministerial Task Team (MTT), headed by Prof. John Volmink, investigated the allegations. Their 2016 report $^{12}$ eventually contained 16 recommendations, after finding, for example, that South African Democratic Teachers Union (SADTU) officials tried to force R25000 out of an educator who applied for a principal post in Gauteng in return for the appointment. The Volmink report shows that similar violations took place in the North West, Eastern Cape and Mpumalanga provinces. ${ }^{13}$

More disconcerting than the actual selling of posts through officials' abuse of power, officially confirmed by the Volmink report, ${ }^{14}$ is the fact that Government has not reacted since the release of the report in 2016. Contrary to promises of giving top priority to education, nobody has, to date, been further investigated or held accountable. In a statement on 27 May 2016, the day when the report was tabled in Parliament, the Democratic Alliance (DA) stated that there are signs that the report "will be swept under the carpet". ${ }^{15}$ The party pointed out that Minister Motshekga was not even present to table the report that she had personally commissioned: "The Minister's absence is inexplicable given that it is a report of a Ministerial Task Team. The only explanation is that she is beginning to distance herself

10 Kubheka "Zuma: Education a primary weapon for SA's economic transformation", http://ewn.co.za/2017/01/24/zuma-education-is-primaryweapon-for-sa-s-economic-transformation (accessed on 2 May 2017).

11 Corruption Watch Annual Report, https://www.corruptionwatch.org.za/wpcontent/uploads/2017/02/Corruption-Watch-Annual-Report-27-02-2017-LowRes-Version.pdf (accessed on 3 March 2018).

12 Volmink https://www.gov.za/sites/default/files/Ministerial_Task_Team_Posts_ Educators_Report2016.pdf (accessed on 24 July 2016).

13 See https://www.da.org.za/2016/05/Jobs-for-cash-signs-that-report-will-beswept-under-the-carpet (accessed on 23 May 2016).

14 Volmink https://www.gov.za/sites/default/files/Ministerial_Task_Team_ Posts_Educators_Report2016.pdf (accessed on 24 July 2016).

15 See https://www.da.org.za/2016/05/Jobs-for-cash-signs-that-report-will-beswept-under-the-carpet (accessed on 23 May 2016). 
from a report that is damning of the ANC's alliance partner, SADTU."16 A prolonged lack of accountability among the political leadership contributed to this, but the expectation has been created in 2018, when President Ramaphosa was elected, that there is new hope in this regard. ${ }^{17}$

\subsubsection{Functionality of public education}

At present, South African public education shows a number of contrasting elements. The public-school system includes two discernible subsystems. Not necessarily geographically far from one another, examples can be found, on the one hand, of successful, well-performing schools, characterised by effective management systems, resulting in academic achievements that compare well to the best in the world. On the contrary, there are those, regrettably by far the majority, that are underachieving. This second subsystem includes an inadmissibly large percentage of dysfunctional schools (an estimated 80 per $\operatorname{cent}^{18}$ ), when compared to international standards. ${ }^{19}$

Every year the National Department of Basic Education (DBE) applauds minor increases in the matriculation pass rates. This can, unfortunately, not hide the fact that the South African education accomplishments are, on average, significantly worse than several much poorer African countries. The International Study Centre at the Lynch School of Education in Boston, United States of America, offers annual international benchmarking statistics in the form of the annual Progress in International Reading Literacy Study (PIRLS) and Trends in International Mathematics and Science Study (TIMMS) reports. Spaull regards the very low scores among South African schools in 2016 as devastating. ${ }^{20}$ These results are obviously the direct consequence of unsuccessful teaching and substandard levels of school management in numerous schools. These are indicators of the miserable condition of public education in South Africa, without doubt impacting on educator security.

It would not be far-fetched to find a causal link between such a generally floundering education system and the lack of skills and diligence of some educators employed in the system. An important question is whether the system is failing, due to incompetent and indolent educators,

16 See https://www.da.org.za/2016/05/Jobs-for-cash-signs-that-report-will-beswept-under-the-carpet (accessed on 23 May 2016).

17 See https://www.news24.com/Columnists/MaxduPreez/a-new-era-ofmodern-leadership-has-dawned-under-ramaphosa-20180116 (accessed on 25 September 2018).

18 See https://www.pressreader.com/south-africa/the-citizenkzn/20111209/281694021608032 (accessed on 2 October 2014).

19 Colditz "Education problems: Are Afrikaans schools to blame?", https://m. news24.com/Columnists/GuestColumn/education-problems-are-afrikaansschools-to-blame-20180118 (accessed on 17 February 2018).

20 Spaull "The unfolding reading crisis: The new PIRLS 2016 results", https:// nicspaull.com/2017/12/05/the-unfolding-reading-crisis-the-new-pirls-2016results (accessed on 17 February 2018). 
or whether the majority of educators are underperforming because of the ailing system. Careful case-by-case inquiries may point out whether an educator is the victim or the culprit.

The types of threats to educator security vary. Some schools are characterised by a physically unsafe environment, ${ }^{21}$ while in others psychological insecurity is on the increase. ${ }^{22}$ Regrettably, the current national scenario still carries many negative elements characteristic of the situation that prevailed shortly after the turn of the millennium when the empirical research, about which this article reports, was conceptualised and the data collection began. At that time, in 2005, a Human Sciences Research Council (HSRC) survey ${ }^{23}$ pointed out that 55 per cent of the responding educators revealed that they intended to resign from the profession, due to low salaries, increased workload, and negative prospects in their career development. Educators reported emotional insecurity, as well as a lack of job security and physical protection.

\subsubsection{Unionism and departmental incompetence}

In scrutinising the current education scenario in an attempt to identify reasons for the prevailing negative situation that has a negative impact on educator security, two influencing factors stand out. First, the devastating influence certain trade unions have on education at national, provincial and school level ${ }^{24}$ and, secondly, the incompetence of the vast majority of units within numerous provincial departments of education, especially at district level..$^{25}$

The first factor is due to two prominent distinguishable phenomena in the current unfolding of the education scenario. First, there is a lack of professional diligence among some educators, ${ }^{26}$ with thousands of educators demanding employment benefits by way of aggressive, violent strike actions, while the rights and interests of learners are seriously violated, and the image of the profession is tarnished. Secondly, many schools are politicised by certain unions that have a predominantly nonacademic approach to education, abusing campuses for political motives and personal gains within the associated political structures. These political activities forced policymakers to include, in 2011, sec. 33A of the South African Schools Act ${ }^{27}$ (hereafter the Schools Act), in which political actions are forbidden during school time, including "campaigning, the

$21 \quad$ Lessing \& Dreyer 2007:120.

22 Masitsa 2011:163-174.

23 Anon 2005:4.

24 Landman 2011:2.

25 Van der Rheede 2010; SAPA 2011; Hoërskool Ermelo v Head of Department of Education, Mpumalanga [2008] 219/2008 SCA); Colditz https://m.news24. com/Columnists/GuestColumn/education-problems-are-afrikaans-schoolsto-blame-20180118 (accessed on 17 February 2018).

26 Rossouw 2010:63.

27 South African Schools Act 84/1996. 
conducting of rallies, the distribution of pamphlets and fliers, and the hanging or putting up of posters and banners". Through this amendment it is specified that "[a] member of a political party may not, for the purposes of conducting party-political activities, encroach on the school time". It is also prohibited "that party-political activities may be conducted at a school during school time determined by the governing body of the school". Jansen heavily criticised this dominance of teacher unions, when he mentioned that South Africa is one of few countries in the world "in which the unions rather than government run the schools". ${ }^{28}$ The effect of the amendment of the Schools Act remains to be seen.

The second factor, namely the incompetence of provincial departments of education, was illustrated by the 2011 ruling against the DBE in FEDSAS and others v MEC, Dept of Basic Education, Eastern Cape. ${ }^{29}$ The Department was consequently put under administration. This apparent incompetence in the education system can be ascribed to the employment of staff without the necessary knowledge, experience, or work ethics that are required for proper service delivery, as also in Maritzburg College $v$ Dlamini NO \& others. ${ }^{30}$ A preoccupation with transformation during appointments, where proven expertise is deemed to be less important than either political affiliation or reaching affirmative action targets, can be viewed as one prominent reason, as was the case in Governing Body Point High School v Head of Western Cape Education Department. ${ }^{31}$

Schools that function effectively are regularly under fire and receive much negative attention by officials of departments, leading to court cases such as The Governing Body of Mikro Primary School v The Western Cape Minister of Education, ${ }^{32}$ and the Overvaal case ${ }^{33}$ in 2018 regarding the application of language policies and alleged discrimination by SGBs. During the past decade, relevant court cases, in which the rulings more often than not went against the respective departments of basic education, created the impression that government officials avoid rather than address the ineffectiveness of numerous dysfunctional schools. Poor teaching by unprofessional educators is not challenged effectively, frequently due to the improper protection from teacher unions. A prominent consequence of the current situation is the gradual demise of discipline in numerous schools. The increase of a general lack of respect in society is also visible in schools. The unprofessional conduct by ill-disciplined or unmotivated educators and poor school management inevitably result in misbehaving

28 Jansen 2010:8.

29 FEDSAS and others v MEC, Dept of Basic Education, Eastern Cape 2011 60/2011 EC.

30 Maritzburg College v Dlamini NO \& others [2005] JOL 15075 (N).

31 Governing Body Point High School v Head of Western Cape Education Department [2006] 14188/2006, Cape of Good Hope.

32 The Governing Body of Mikro Primary School v The Western Cape Minister of Education [2005] 332/2005 Cape of Good Hope.

33 Anon "Education department loses Overvaal school admissions case", https:// www.sowetanlive.co.za/news/south-africa/2018-01-15-education-departmentloses-overvaal-school-admissions-case/ (accessed on 2 March 2018). 
learners and, in severe cases that do exist, a total lack of control. Criminal learner conduct and occurences of crimen injuria aimed at educators are not uncommon. ${ }^{34}$ As a result of the above negative elements in the South African education scenario, education as a profession is at risk. In a system that is partially dysfunctional, educator security is threatened in various ways, and the rights of diligent educators are at stake. In sec. 24 of the Bill of Rights, the Constitution affords everyone the right to "an environment that is not harmful to their health or wellbeing", while sec. 23 stipulates that everyone has the right to fair labour practices. Despite these provisions and labour legislation developments over the past decade, seriously attempting to protect the interests of all employees in South Africa, a large percentage of educators perceive that their fundamental and employment rights are ignored. ${ }^{35}$

\section{Conceptual framework}

To ensure a proper comprehension of the meta-synthesis of the empirical data, a brief discussion of the most salient concepts related to the central argument is offered next. It should be noted that the data analysed in this article all stem from Education Law Studies.

\subsection{Education law and Education Law research}

The academic research discipline Education Law should be distinguished from education law as that body of statutes and other legal sources that apply to education, which regulate school activities, prominent in education-related court cases and other instances such as industrial action. From a Canadian point of view, Brown and Zuker ${ }^{36}$ regard Education Law as "a dynamic, invigorating, and intellectually stimulating discipline that is constantly evolving". Russo and Stewart ${ }^{37}$, respectively from the United States of America and Australian perspectives, accept Education Law as an academic discipline and draw attention to the fact that education law should constantly be developed "to meet the needs of today's schools". Concepts such as justice, as promoted by Beckmann, ${ }^{38}$ and geborgenheit, as advocated by Oosthuizen, ${ }^{39}$ underpin the ontological premise of Education Law in South Africa.

The ontological basis for research in Education Law should be clearly distinguished from that of Education Law as a research discipline or academic subject. Despite the fact that Education Law is an established legal discipline, research in Education Law is not conducted in the way legal academics follow. Defining the nature of legal research from a predominantly

34 Masitsa 2007:155; Wolhuter \& Van Staden 2007:293.

35 Du Plessis \& Conley 2007:42.

36 Brown \& Zuker 2002:v.

37 Russo \& Stewart 2001:19.

38 Beckmann 2013.

39 Oosthuizen 2009:15. 
American legal perspective, Russo ${ }^{40}$ contends that "systematic inquiry in the law is a form of historical-legal research that is neither qualitative nor quantitative". Legal research in South Africa traditionally entails primarily the analysis of legal determinants (the Constitution and other statutes), case law and the South African common law as it was inherited from the Roman-Dutch and English legal systems. Education Law research, unlike legal research, often includes empirical research through a variety of qualitative or quantitative data-generating methods. Education Law researchers, besides setting up a legal framework, are also interested in capturing and understanding stakeholders' perceptions, or to predict certain effects of legal provisions.

\subsection{Labour relations and labour law}

Rossouw $^{41}$ explains that labour relations refer to all relations or relationships between the different parties: employers, employees, and the state. This includes the primary relationship between employer and employee, or groups of each (such as employer organisations and unions). Van Jaarsveld and Van $\mathrm{Eck}^{42}$ define labour law as a set of objective legal principles that regulate the legal relationships between employers and employees on both collective and individual level, between employees and fellow employees, between different employers, as well as between employees, employers and the state, the latter being responsible for regulating the relationships by means of, inter alia, legislation.

\subsection{Educator professional security}

For the purpose of this article, the concept 'professional security' includes both psychological security and physical safety, unless otherwise specified. Rossouw ${ }^{43}$ defines professional security as follows: "Fundamentally, professional security can be regarded as the physical and psychological safety an employee experiences in the school as a workplace." The underlying premise of this definition is the educator as professional employee, against the theoretical framework of labour law.

Bothma $^{44}$ also used the term 'professional security', but in the higher education context. She identified "legal, environmental and psychological security" as elements of lecturer professional security. This concurs with the definition offered by Rossouw, ${ }^{45}$ in that physical wellbeing (including safety), psychological factors and a legal underpinning form the pillars on which professional security rests. This definition will be used for the purpose of this article.

40 Russo 2005:42.

41 Rossouw 2010:8.

42 Van Jaarsveld \& Van Eck 1994:25.

43 Rossouw 2014:2.

44 Bothma 2015:273.

45 Rossouw 2014:13. 
In South African public education, educators' professional security is influenced by a variety of factors associated with schools and the school system. Some of these factors will be discussed in this article. Literature indicates that many educators in South African public and independent schools have to cope with unfair labour practices. The reasons for this are excessive workloads, incompetent or inapt employer support, shortcomings in their employment contracts, and undue pressure from parents and learners.

\section{Research questions}

Education has regularly been declared a national priority, but the publicschool system is in a state of disarray. One may argue that improved professional security of educators is one important factor towards remedying the deteriorating school system.

Against the grim background portrayed in the above problem statement, a central research question has been formulated, namely: What deeper insight into educator professional security in South Africa can be reached by means of a literature overview and an analysis of legal determinants as well as a meta-synthesis of the findings of a selected set of completed studies?

Over a period of more than a decade, a variety of Education Law studies were conducted. These formed part of a NRF-funded project entitled Educator security and educator rights in a changing education environment. Within this project, several master's and doctoral studies were completed after national and international assessments, academic papers had been presented, and a number of academic articles had been published. The main research objective of this article is, therefore, to gain, through a meta-synthesis of the findings of a set of completed studies, deeper insight into selected elements of educator security. Characteristic of a meta-synthesis, the insight gained will stretch beyond the sum of the individual studies and will guide the researchers to a deeper understanding of the phenomenon of educator security in a variety of educational settings.

In order to answer the above question, we first determined the nature of the environments that impact on educator security. We also indicated the nature of educator professional security, followed by a meta-synthesis of the findings of a selected set of completed studies, in order to gain new insight into educator professional security.

\section{Research design and method}

In light of the research question, the interpretative phenomenological approach was regarded as an appropriate paradigm. This study analysed and synthesised past studies (from 2004 to 2017) conducted on educator security through a qualitative meta-synthesis. The meta-synthesis approach 
stems from quantitative research in the field of human sciences. ${ }^{46}$ This method is, however, not included as a qualitative method in authoritative scholarly work on research methodology. ${ }^{47}$ The meta-synthesis approach is used as a method in this article, based on the inherent advantages discussed below to enable us to answer our research questions.

\subsection{Meta-analysis and meta-synthesis}

Regarding the two concepts 'meta-analysis' and 'meta-synthesis', the interrelatedness of these two concepts is of importance. Meta-analysis will be discussed first, in order to properly comprehend the nature of meta-synthesis. From a quantitative perspective, meta-analysis can be described by first referring to primary and then to secondary analyses. ${ }^{48}$ Primary analysis is "the original analysis of data in a research study", while secondary analysis is "the re-analysis of data for the purpose of answering the original research question with better statistical techniques, or answering new questions with old data", and lastly, meta-analysis is "the analysis of analyses"49. Qualitative meta-analysis follows the same reasoning as quantitative meta-analysis - the researcher attempts to administer the process of secondary analysis on primary findings. ${ }^{50}$ Qualitative meta-analysis has an interpretative nature and thus differs from a quantitative meta-analysis process, which is more deductive..$^{51}$ The main idea of qualitative meta-analysis is to offer a to-the-point, all-inclusive overview of findings that were conducted by several researchers on a specific theme. ${ }^{52}$ Moving to the notion of 'meta-synthesis', Sandelowski and Barrosso ${ }^{53}$ suggest three approaches to meta-synthesis: to synthesise the findings of multiple studies conducted by one researcher; to synthesise findings of studies conducted by multiple researchers in the same field, or to summarise main features across qualitative studies quantitatively. The term 'qualitative meta-synthesis' was coined in 1985 by Stern and Harris. ${ }^{54}$ Sandelowski ${ }^{55}$ defines it as "an interpretive integration of qualitative findings that are themselves interpretive syntheses of data". As Walsh and Downe state, the qualitative meta-synthesis process is hermeneutic in nature - the researcher wishes to understand and explain a certain phenomenon. ${ }^{56}$

Meta-synthesis can be distinguished from other forms of synthesis, as other forms focus mostly on summarising the original data. When a

46 Glass 1976.

47 Babbie 2014; Creswell 2013; De Vos et al. 2011; Maree 2016; Miles et al. 2014.

48 Glass 1976:3.

49 Glass 1976:3.

50 Timulak 2009:591.

51 Finfgeld 2003:894.

52 Finfgeld 2003:894.

53 Sandelowski \& Barrosso 2007:18.

54 Walsh \& Downe 2004:204.

55 Sandelowski \& Barrosso 2007:18.

56 Walsh \& Downe 2004:204. 
researcher conducts a meta-synthesis, the main purpose is to convert the original data into a renewed, extended understanding of the phenomenon under analysis. ${ }^{57} \mathrm{~A}$ meta-synthesis aims to conduct an integrated interpretation of findings from various studies. ${ }^{58}$ This integration provides the researcher with a vast and deeper understanding of the primary findings. ${ }^{59}$ These primary findings are, on their own, interpretive syntheses of the original data - thus integrated clarifications of a certain phenomenon. ${ }^{60}$ Moreover, meta-synthesis gives significant meaning to a group of studies, due to a mutual link between concepts that occur. ${ }^{61}$ These individual studies can benefit from forming part of meta-synthesis. However, the value of single studies should never be ignored, as they contain the primary findings. ${ }^{62}$ Meta-synthesis has a worthy purpose, as it provides the researcher the opportunity to develop and reflect. ${ }^{63}$ Therefore, a qualitative meta-synthesis is deemed to be a suitable research method. In this present research, the researchers aimed to gain deeper insight into educator security by synthesising the findings of a set of completed studies.

\subsection{Data collection}

The researchers had an existing data set at their disposal. The primary studies formed part of an overarching project entitled Educator security and educator rights in a changing education environment funded by the National Research Foundation (NRF). The data set consisted of the findings compiled from eight masters' and four doctoral studies in the field of education law, all focussed specifically on educator security. These primary studies were deemed to be both suitable and adequate data for this meta-synthesis and further data collection was not considered.

\subsection{Data analysis approach}

Bondas and Hall's meta-synthesis process ${ }^{64}$ consists of two phases, namely the developmental process and the meta-process. The developmental process occurs when synthesis takes place methodologically or theoretically, and the meta-process follows when the researcher goes further than the original studies intended to go. The two processes following each other can be described as a thematic synthesis process. ${ }^{65}$ Thomas and Harden identified three stages that form part of thematic synthesis: "the coding of text 'line-by-line'; the development of 'descriptive themes',

57 Barnett-Page \& Thomas 2009:8.

58 Barnett-Page \& Thomas 2009:8.

59 Barnett-Page \& Thomas 2009:8.

60 Thorne et al. 2004:1358.

61 Bondas \& Hall 2007:115.

62 Bondas \& Hall 2007:115.

63 Bondas \& Hall 2007:116.

64 Bondas \& Hall 2007:116.

65 Bondas \& Hall 2007:116. 
and the generation of 'analytical themes"'. ${ }^{66}$ When the researcher develops these descriptive themes, the analysis is still closely allied to the primary studies. As soon as the researcher begins to generate analytical themes, the process goes beyond the primary studies. ${ }^{67}$

For the purpose of this study, we adapted this process, as illustrated in Figure 1. The researchers initially analysed the findings of the individual studies, in order to establish which matters emerged as having the most prominent influence on educator professional security (meta-analysis process). In this study, the analysis was conducted by means of a secondary analysis, which is associated with meta-analysis. De Vos et al. ${ }^{68}$ state that secondary analysis is the re-analysis of an existing data set. The researcher who conducts secondary analysis has a different purpose than the primary researcher and benefits from the many advantages secondary analysis offers. ${ }^{69}$ Some of these advantages include: this technique assists the researcher with the verifying of data; it develops a sound scientific stance, and it is retrospective, thus providing the researcher with reflection opportunities ${ }^{70}$. Consistent with the approach proposed by De Vos et al., we reduced the data to only retain the most prominent elements. Thereafter, we reflected on these selected elements (as the meta-synthesis process) to gain new and deeper insight.

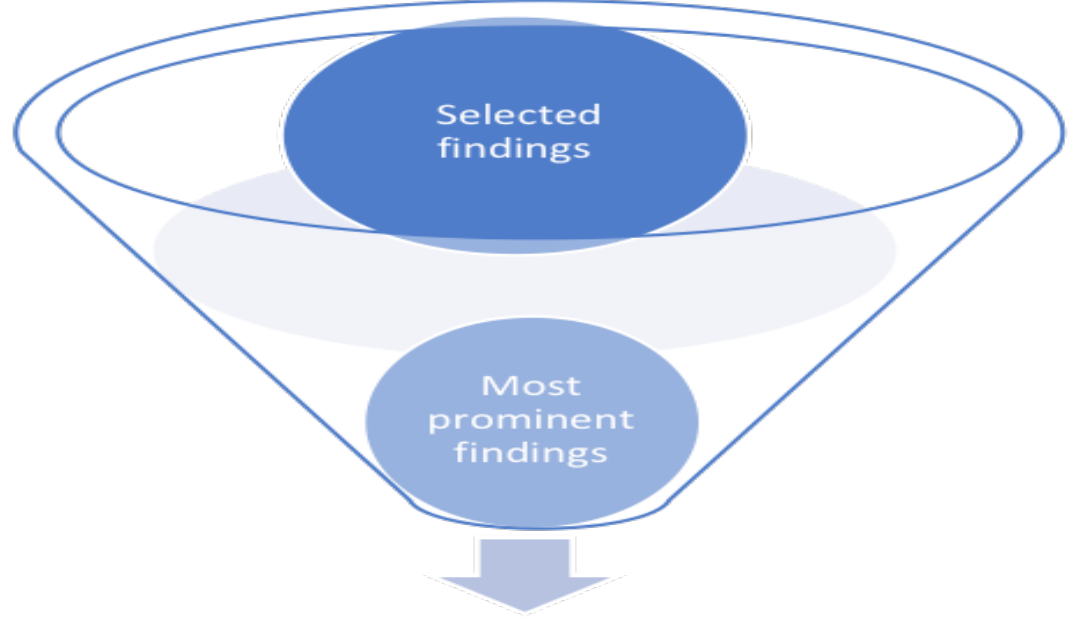

Figure 1: Meta-synthesis

Results of the secondary analysis will be presented next, leading to the meta-synthesis consisting of the most prominent findings, and to end, a concluding distillation is offered.

66 Thomas \& Harden 2008:1.

67 Thomas \& Harden 2008:1.

68 De Vos et al. 2011:385.

69 De Vos et al. 2011:385.

70 De Vos et al. 2011:385. 


\section{Research results}

All the research questions focussed on specific aspects of the same phenomenon, namely educator security and educator rights. The research questions and aims of the respective studies varied significantly, because they were related to the unique contexts associated with the studies. Similarly, the respective research designs were tailored according to the various contexts, but all were characterised by an interpretative phenomenological approach, leading to qualitative studies. Based on their similarities, the studies are, to a great extent, comparable.

The first phase of the secondary analysis was to establish the themes that emerged from the dataset, namely lack of basic legal knowledge and application of legal principles; employer support; rights of the child; uncertainty about who the employer is; discipline; curriculum changes and workload; unions, as well as educator misconduct and legal liability. During the second phase of the secondary analysis, all the themes were clustered into four broad categories, according to the way in which the matters related to the various stakeholders' influence, educator security and educator rights. These were matters related to the educator, learner, union and employer (and principal). Figure 2 presents a synoptic overview of categories and themes.
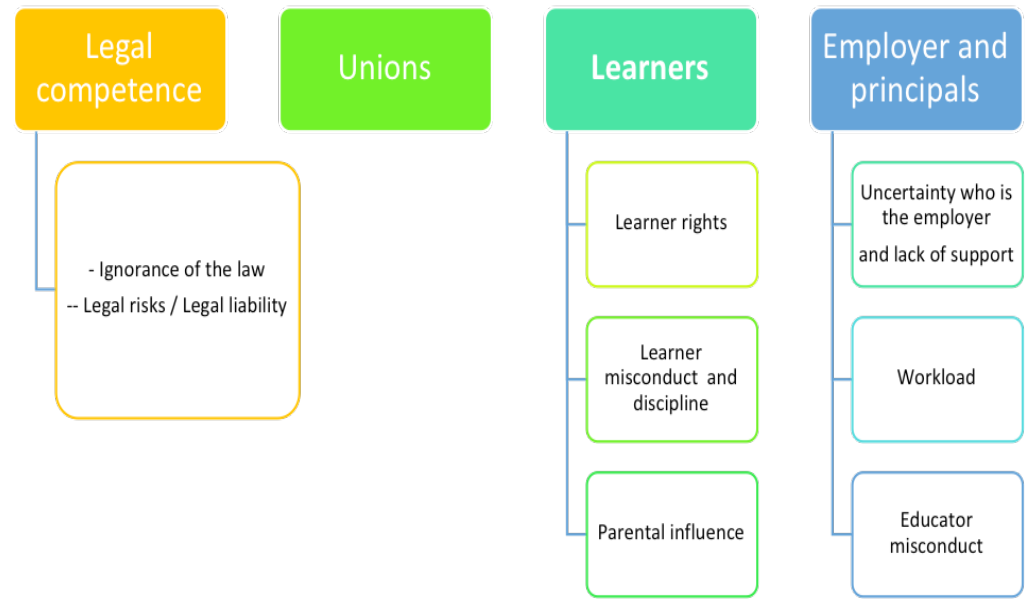

Figure 2: Categories and themes: Stakeholder-related matters that influence educator security

\subsection{Legal knowledge}

The meta-analysis yielded two themes regarding legal knowledge, namely partial or total ignorance of the law among educators, and concomitant legal risks and liability. 


\subsubsection{Ignorance of the law}

Several studies completed during the period and reported in this research highlight that the absence of legal knowledge, even on a basic level, leads to injustice and the incompetent application of legal principles. This applies to educators, school principals, school-governing body members as well as departmental officials. There is no doubt that such ignorance places these role players in a vulnerable position. It obviously also jeopardises the position of learners under their care and heightens the risks associated with liability matters.

In 2006, Van Staden ${ }^{71}$ found that the educators who partook in his study had hardly any knowledge of which laws protect their rights. This implies that the educators, due to their lack of knowledge, did not realise that there is adequate legal protection of their rights. The majority of the participants felt that they had the right to fair labour practices, but they were not aware of the relevant legislation that enforces it. Consequently, the majority of the participants did not know who their actual employer was, and wrongly assumed that it was the principal.

Consonant with the findings of Van Staden, Bartlette's ${ }^{72}$ empirical investigation pointed out that almost all of the participants in her study showed poor knowledge of labour and other legislation. The participants vaguely stated that some legislation exists, but educators demonstrated limited knowledge of the legislative provisions aimed at protecting the safety and security of the person..$^{73}$ In some instances, no knowledge in this regard was evident, obviously leading to a lack of security.

Focusing on the Foundation Phase, Keating, ${ }^{74}$ in turn, found that few participating Foundation Phase educators could speak with authority on legal issues pertaining to learner discipline. In her interpretation, she stated that this may lead, in part, to the perception that "learners have more rights than educators". Educators are frequently not offered the necessary protection with issues pertaining to learner conduct. This makes it difficult to retain their positions as authority figures. Educators then lack the security of knowing that the DBE will protect their best interests.

Also involving educators from the Foundation Phase, Rossouw ${ }^{75}$ found a lack of knowledge specifically of contractual stipulations, labour law and common law principles regarding employment conditions that regulate their working lives. This leads to serious insecurity as these educators do not know how to protect themselves from possible exploitation in the workplace and unfair appointment procedures. Rossouw states the following: "Although some participants felt that they sometimes received

71 Van Staden 2006:180.

72 Bartlette 2013:132.

73 Bartlette 2013:127.

74 Keating 2011:131.

75 Rossouw 2011:150. 
callous treatment by the employer, they were evidently not equipped to claim their constitutional rights." ${ }^{\prime 76}$

Regarding legal matters pertaining to learner conduct and its impact on educator security, Mans ${ }^{77}$ found that ill-discipline was often handled incorrectly, due to ignorance of the law of both educators and principals at the participating schools. Mans ${ }^{78}$ attributed this ignorance, inter alia, to educators being generally unmotivated and, therefore, not interested in broadening their legal horizons. She found that this disinterest was the (often erroneous) perception that union representatives have adequate legal knowledge to act as quasi-lawyers in cases of misconduct and, therefore, other educators do not have to be knowledgeable in this regard themselves.

In his study on the security of beginner educators, De Wet ${ }^{79}$ found that this group of young educators were aware of the existence of legislation but, despite being exposed to Education Law during their training, they were ignorant of the content, function, operation and application of legislation. Educators, therefore, remain ignorant of their own employment rights and duties. Ignorance about legislation in this regard leads to an uncertainty about exactly what their obligations are and which rights they have. The uncertainty goes further, as beginner educators are also unsure of their employer's rights and duties. They do not know what they can expect from the employer. This uncertainty is a threat to beginner educators' security.

Rutherford's ${ }^{80}$ empirical study also found that participants were clearly unaware of their rights to protection under the law and were not experiencing such protection in their schools. None were informed about the content of the Bill of Rights or other legislation that should grant them protection from stress and psychological insecurities at work.

In 2017, Liwane ${ }^{81}$ confirmed that the majority of educators' and departmental officials' knowledge of legislation and application thereof was very poor. Her empirical study also confirmed that some educators do have general or basic knowledge and understanding of legislation. In instances where such knowledge was found, they still did not know how to apply it effectively. For example, educators do not always enjoy exercising their right to teach, due to learner ill-discipline, thus putting such educators in a vulnerable position.

\subsubsection{Legal risks and accompanying liability}

Despite the existence of legislation, it was found that the participants showed ignorance regarding the applicable laws. ${ }^{82}$

76 Rossouw 2011:150.

77 Mans 2015:122.

78 Mans 2015:128.

79 De Wet 2015:104.

80 Rutherford 2009:209.

81 Liwane 2017:238.

82 Bartlette 2013:131. 
Ignorance of liability among some principals and their insufficient knowledge of the developmental profile of Grade R learners ${ }^{83}$ lies at the heart of some principals' inability to make judicious and wise decisions. For example, compulsory attendance of staff meetings twice a week before the start of school, when learners arrive, places Grade R educators in a position where they are likely to neglect their legal responsibility for supervision. This may result in them being held delictually liable.

Rossouw $^{84}$ also found that there are several ways in which language matters pose liability challenges for educators. Some Grade R learners have not properly mastered the language of instruction, which puts pressure on educators' liability for their security, because they experience difficulty in communicating security measures. Moreover, the situation has been found at schools where an educator has not mastered the African mother tongue of those learners whose parents prefer English as the language of instruction. Consequently, in an emergency, communication with parents is difficult, if not impossible, as they cannot communicate in the language of instruction.

\subsection{Unions}

De Wet $^{85}$ focussed on beginner educators' security and found that several were uncertain and uninformed about the exact aim, function and functioning of teacher unions and, therefore, did not experience the security that a teacher union can offer. The majority of the participants were also unaware of the procedures pertaining to industrial action and the legal determinants, as contained in the Labour Relations Act (LRA) that regulates strikes.

Educators trust their union representatives to act as "lawyers" and successfully defend their cases, or face the resulting "loss of members to another union". ${ }^{86}$ Educators, members of SMTs and officials in the Department, on the other hand, were found to only have superficial knowledge of the law. This is easily exploited by shrewd union representatives to get wrongdoers acquitted. The importance and relative absence of appropriate legal knowledge is thus emphasised again. Union representatives will not be able to control situations to benefit offenders when educators and managers, in particular, have adequate legal knowledge and follow the correct procedures.

Although unions officially pronounce a stance against educator misconduct, members of such unions openly committing misconduct, according to Mans' findings, are not brought to justice. To allow such undisciplined conduct, as displayed during strikes and otherwise, and to

83 Rossouw 2011:157-159.

84 Rossouw 2011:157-159.

85 De Wet 2015:106-107.

86 Mans 2015:130. 
go unpunished is to contribute to the cultivation of undisciplined educators, setting an undesired, negative example for the learners.

The study conducted by Liwane ${ }^{87}$ confirmed that teacher unionism has diluted professionalism in South Africa's public education. The empirical study further confirmed "how readily the majority of educators would desert their classrooms in preference for taking their issues to the streets when an impasse is reached during salary negotiations".

Moreover, the empirical study confirmed the excessive politicisation of township schools and further revealed that there is bureaucratic interference and incidents of interference by teacher unions during filling of promotional posts. ${ }^{88}$ Both Liwane's literature analysis and empirical data confirmed that the professional status or identity of educators has become complex and dynamic, since the majority of unionised educators nowadays perceive themselves as workers: ${ }^{89}$ "Unionism in South African public education, as the qualitative comments of participants confirmed, is unregulated and self-serving."

\subsection{Learners}

Various matters specifically related to learners could influence educators' professional security. These matters pertain to learner rights; learner misconduct and discipline; and parental responsibility and influence.

\subsubsection{Learner rights}

In Liwane's study, educators believed that learners have too many rights compared to their own constitutional rights. ${ }^{90}$ Educators in the study also indicated that ill-discipline affected their right to teach. This matter will be discussed below. Various researchers ${ }^{91}$ concluded that educators believe that the rights of children are overemphasised and that their own rights are not acknowledged. These negative feelings have a direct negative impact on educators' security.

\subsubsection{Learner misconduct and discipline}

Rutherford determined that learner ill-discipline is causing serious psychological insecurities for educators in schools. ${ }^{92}$ Liwane's empirical research indicated that educators and learners from township schools experienced severe violence from learners, such as gangsterism. ${ }^{93}$ Despite

87 Liwane 2017:249.

88 Liwane 2017:251.

89 Liwane 2017:252.

90 Liwane 2017: 237.

91 De Wet 2015:105; Rutherford 2009:207; Keating 2011:131; Van Staden 2006:180.

92 Rutherford 2009:209.

93 Liwane 2017: 239. 
the existence of codes of conduct at schools, educators feel threatened by learner misconduct, ${ }^{94}$ and by the fact that some colleagues either ignore the code or implement it ineffectively or inconsistently. This noncompliance of the code by some colleagues causes a risk for those who do comply: learners disfavour them and target them in a violent manner. ${ }^{95}$ Moreover, De Wet ${ }^{96}$ found that educators and beginner educators, in particular, are unclear about acceptable ways to discipline learners - this uncertainty makes them feel incompetent ${ }^{97}$ Besides the uncertainty, educators opine that they have hardly any or no resources to handle misconduct in class and that the DBE offers neither instructions nor support in this regard. ${ }^{98}$

\subsubsection{Parental responsibility and influence}

In addition to the above, many educators believe that parents neglect their primary duty as caregivers by not taking up their responsibility to teach their children fundamental values such as respect, honesty, obedience, and integrity. ${ }^{99}$ Keating asserts that the link between home and school discipline is found wanting, since "many learners are not taught acceptable behaviour at home - the onus is on the educator to fulfil this role". ${ }^{100}$ Thus, in addition to their daily curriculum-related duties, educators become the primary or only educator to teach learners basic acceptable behaviour. ${ }^{101}$ This phenomenon impacts negatively on their educator security, as it places an unfair burden on them to fulfil this expanded parental role in addition to their other responsibilities. ${ }^{102}$

Rutherford found that educators often referred to parents as part of the discipline problem, due to their lack of respect and support for educators. ${ }^{103}$ Parents discuss educators in a negative light in front of their children, and this exacerbates the fact that children do not accept authority from school. ${ }^{104}$ Learners are under the impression that their parents' money and status can "bail" them out of any situation. ${ }^{105}$ In fact, educators feel powerless. ${ }^{106}$ In contrast with these findings, Liwane ${ }^{107}$ found that parents from township schools are not partaking in their children's education at home nor participating at their schools. She links this to the no-fee status of some schools, discouraging some parents to feel part of the school.

\footnotetext{
94 Bartlette 2013:128.

95 Barlette 2013:128.

96 De Wet 2015:109.

97 Mans 2015:125; De Wet 2015:109.

98 Rutherford 2009:209.

99 Keating 2011:134; Rossouw 2011:160.

100 Keating 2011:134.

101 Keating 2011:134.

102 Rossouw 2011:160.

103 Rutherford 2009:207.

104 Bartlette 2013:133.

105 Bartlette 2013:133.

106 Bartlette 2013:133.

107 Liwane 2017:238.
} 


\subsection{Employer and principals}

The employer, being the DBE, as well as the principal of the school impact on the professional security of educators. Educators are uncertain of who exactly their employer is and they experience a lack of support from their employer. Matters such as workload and educator misconduct also have an effect, as will be discussed.

\subsubsection{Uncertainty regarding who the employer is and lack of support}

Educators are uncertain of who exactly their employer is. Many of them are under the impression that they are in the service of the principal, instead of the DBE. ${ }^{108}$ Educators are also unaware of the employer's responsibilities towards them. ${ }^{109}$ Several educators are of the opinion that the employer, the DBE, does not provide them with the much-needed support to fulfil their duties. ${ }^{110}$ Rutherford found that many educators perceive the DBE as an additional stressor. ${ }^{111} \mathrm{Her}$ study also indicated that some educators experienced their principals and school-governing bodies as supportive. ${ }^{112}$

\subsubsection{Workload}

The excessive and consistently escalating workload of educators has caused psychological insecurity for many of them. ${ }^{113}$ Educators have seemingly endless administrative duties and are of the opinion that this hinders effective teaching. ${ }^{114}$ Furthermore, constant changes with regard to the curriculum, school policies and portfolio requirements increase educators' paperwork and, in fact, their workload. These continual changes are stressful and overwhelming, impacting negatively on the wellbeing of educators. ${ }^{115}$

\subsubsection{Educator misconduct}

Mans ${ }^{116}$ found that educator misconduct of fellow educators has, to a large extent, an effect on educators' security. Participants mentioned that educators are often absent; they are not in their classes when they should teach, and there are even cases of sexual relationships with learners. Liwane ${ }^{117}$ confirmed that educators are often absent from schools - some

108 De Wet 2015:106; Van Staden 2006:182; Rossouw 2011:151.

109 De Wet 2015:106.

110 Bartlette 2013:131; De Wet 2015:110; Keating 2011:132.

111 Rutherford 2009:209.

112 Rutherford 2009:209.

113 Rutherford 2009:207; Mans 2015:125.

114 Keating 2011:136.

115 Mans 2015:125; Rutherford 2009:207; Keating 2011:132.

116 Mans 2015:122.

117 Liwane 2017:248. 
even perceive it as a right, instead of something that should happen rarely during a school term.

\section{Synthesis}

To gain new insight into educator professional security, the researchers used the most prominent findings. They scrutinised the interrelatedness of these findings and generated the most salient implications for practice.

\subsection{Legal competence}

The meta-analysis yielded a number of valuable guiding principles associated with a lack of legal knowledge, which can steer the process of enhanced professional security for educators. First, several educators do not realise the protection the law has to offer and, therefore, increase their vulnerability through their ignorance. This vulnerability is particularly visible in the erroneous belief, among some educators, that learners have more rights than educators. This conviction is boosted when the legal principle related to the best interests of the child is wrongly interpreted by officials and principals as indicating that the child should always have things his/her way, irrespective of the seriousness of the misconduct. In the process, when investigations are conducted and disciplinary steps are taken, the perpetrator may become the victim, with the educator landing in the dock as the accused.

Secondly, all three of the defining components related to professional security, namely physical wellbeing, psychological factors, and a legal underpinning, come into play when educators experience workplacerelated stress and psychological insecurities. This becomes a reality, especially in cases of alleged delictual liability for harm or injury to learners under their supervision, and is aggravated when their superiors (through ignorance of the law) expect certain actions by educators that increase the risk of injury to learners. The educators' insecurity, assuming that they will be held liable in their personal capacity if negligence can be proven, may lead to physical and psychological disorders. Otherwise, they withdraw from all activities with an element of risk and cannot fulfil their tasks as professionals to the extent that is expected. These concerns are based on a lack of awareness of the protection provided by sec. 60 of the Schools Act, according to which the state is held liable for damages to be paid to claimants after injuries or other forms of harm to learners.

In the final instance, union representatives in schools are generally viewed, rightly or wrongly, as being highly knowledgeable regarding the law. This causes individual educators and even principals to rely on these colleagues rather than to expand their own knowledge and legal competence, redoubling their defencelessness. In cases of educator misconduct, wily union representatives may thus abuse such ignorance to prevent the law from being properly applied when it comes to the protection of their members. 


\subsection{Stakeholders}

Different role players such as learners, parents, unions and the employer have an effect on educators' professional security. These role players influence one another in such a way that their actions have a domino effect, which eventually impacts on the educators' professional security.

The escalating workload of educators has emerged in the meta-analysis as a major factor in professional security. The DBE adds to the workload of educators, leading to a sense of discouragement. The ideal situation would be that colleagues support one another, but the findings indicate that the contrary is often the case.

Devoted educators are often under more pressure, because some of their colleagues do not abide by the Code of Professional Ethics of the South African Council for Educators (SACE). Moreover, union members who commit misconduct are seldom taken to task and rarely held accountable; hence, the "diluted professionalism" in South African public schools.

As discussed earlier, the best interests of the child principle is often misunderstood and several educators believe that their own rights are less important. The meta-analysis of the selected studies provided some reasons for this unwarranted perception. Educators perceive that an overemphasis on learners' rights by education authorities and parents fuel ill-discipline of learners. Some studies indicate that parents handicap the discipline system, due to the fact that they do not take primary responsibility for the upbringing of their children. Furthermore, parents do not support educators in the exercising of discipline by actively, through criticism, breaking down their authority. Moreover, conscientious educators experience physical and psychological strain when their colleagues do not properly apply the code of conduct of their schools with regard to the ill-discipline of learners. In addition, the DBE often does not support educators or schools in cases of serious misconduct by learners, which may leave educators feeling stranded. The ill-discipline of learners, unprofessional fellow educators, and lack of parent involvement have a direct and negative impact on the workload of educators, resulting in a damaging domino effect.

\section{Concluding distillation}

The domino effect of stakeholders' actions, as stated, in addition to a lack of legal competence, has a severe effect on professional security. Learner misconduct impacts negatively on professional security. It is recommended that specific attention be paid to this detrimental element in schools. Positive parent involvement has the potential to act as a remedy. Similarly, it was found that unions as organisations as well as their members' involvement, instead of enhancing educator security have, ironically, a severe negative impact on motivated and law-abiding educators. Their support to delinquent educators stands out as a major threat, not only to educator security, but also to the education system as a whole. 
It can be categorically stated that increased legal competence should be considered a key factor in the development or maintenance of educator professional security. Educators are increasingly vulnerable, due to their lack of their own legal knowledge, aggravated by a serious lack of legal competence among departmental officials and principals.

To conclude, it is suggested that the most effective measure against detrimental effects related to learners, the employer, the principal and unions is concerted effort by all role players to increase legal competence.

\section{Bibliography}

\section{ANON}

2005. Many teachers plan to quit. The Herald, 4 April:4.

2018. Education Department loses Overvaal school admissions case. https://www.sowetanlive.co.za/news/south-africa/2018-0115-education-department-loses-overvaal-school-admissions-case/ (accessed on 2 March 2018).

\section{ANBEEK S}

2017. Corruption Watch shakes up South Africa. https://www.hivos. org/corruption-watch-shakes-south-africa (accessed on 21 January 2017).

\section{BABBIE ER}

2014. The basics of social research. $4^{\text {th }}$ edition. Belmont, CA: Thomson Wadsworth.

\section{BARNETT-PAGE E \& THOMAS J}

2009. Methods for the synthesis of qualitative research: A critical review. BMC Medical Research Methodology 9:59. https://doi. org/10.1186/1471-2288-9-59

\section{BARTLETTE NM}

2013. Opvoedersekuriteit en ernstige wangedrag van leerders: 'n Arbeidsregtelike perspektief. Unpublished MEd dissertation, NorthWest University, Potchefstroom.

\section{BECKMANN J}

2013. Personal communication, 19 March.

\section{BONDAS T \& HALL EOC}

2007. Challenges in approaching meta-synthesis research.

Qualitative Health Research 17(1):113-121. https://doi. org/10.1177/1049732306295879

\section{BOTHMA F}

2015. A juridical foundation for accountability to enhance the security of the Higher Education lecturer in South Africa. Unpublished PhD thesis, North-West University, Potchefstroom. 


\section{BROWN AF \& ZUKER MA}

2002. Education Law. $3^{\text {rd }}$ edition. Toronto: Thomson \& Carswell.

CITIZEN, THE

2011. School federation may appeal ruling. https://www.pressreader. com/south-africa/the-citizen-kzn/20111209/281694021608032 (accessed on 22 January 2014).

\section{COLDITZ P}

2018. Education problems: Are Afrikaans schools to blame? https://m. news24.com/Columnists/GuestColumn/education-problems-areafrikaans-schools-to-blame-20180118 (accessed on 17 February 2018).

\section{CONVERSATION, THE}

2017. Grace Mugabe: Why diplomatic immunity isn't always an 'out of jail' ticket. https://theconversation.com/grace-mugabewhy-diplomatic-immunity-isnt-always-an-out-of-jail-ticket-82721 (accessed on 1 September 2017).

\section{CORRUPTION WATCH}

2016. Annual report 2016. http://www.corruptionwatch.org.za/learnabout-corruption/reports/annual-report (accessed on 22 January 2017).

\section{CRESWELL JW}

2014. Research design: Qualitative, quantitative, and mixed methods approaches. $4^{\text {th }}$ edition. Thousand Oaks, CA: Sage Publications.

\section{DEMOCRATIC ALLIANCE}

2016. https://www.da.org.za/2016/05/Jobs-for-cash-signs-thatreport-will-be-swept-under-the-carpet (accessed on 23 May 2016).

\section{DEPARTMENT OF BASIC EDUCATION (DBE)}

2016. Report of the ministerial task team appointed by minister Angie Motshekga to investigate allegations into the selling of posts of educators by members of teachers unions and departmental officials in provincial education departments. https://www.gov.za/sites/ default/files/Ministerial_Task_Team_Posts_Educators_Report2016.pdf (accessed on 24 July 2016).

DE VOS AS, DELPORT CSL, FOUCHÉ CB \& STRYDOM H 2011. Research at grass roots: A primer for the social science and human professions. Pretoria: Van Schaik.

\section{DE WET J}

2015. Die sekuriteit van die beginner-opvoeder as werknemer: ' $n$ Onderwysregtelike perspektief. Unpublished MEd dissertation, NorthWest University, Potchefstroom.

\section{DU PLESSIS PJ \& CONLEY L}

2007. Bullying in schools: Can we turn the tide? Perspectives on learner conduct. Potchefstroom: The Platinum Press. 


\section{DU PREEZ M}

2018. A new era of modern leadership has dawned under Ramaphosa News24. https://www.news24.com/Columnists/MaxduPreez/a-newera-of-modern-leadership-has-dawned-under-ramaphosa-20180116 (accessed on 1 September 2018).

FINFGELD DL 2003. Metasynthesis: The state of the art - So far. Qualitative Health Research 13(7):893-904. https://doi.org/10.1177/1049732303253462

\section{GAN INTEGRITY BUSINESS ANTICORRUPTION PORTAL} 2018. https://www.business-anti-corruption.com/country-profiles/ south-africa/ (accessed on 3 September 2018).

\section{GLASS GV}

1976. Primary, secondary, and meta-analysis of research. Educational Researcher 5(10):3-8. https://doi.org/10.3102/0013189X005010003

\section{JANSEN $J$}

2010. Enhancing teacher professionalism and status promoting recognition, registration and standards. Keynote address at Commonwealth Symposium, Bloemfontein. London: Commonwealth Secretariat, 23-25 March.

\section{KEATING JB}

2011. Security in the workplace of the Foundation Phase educator: An Education Law perspective. Unpublished MEd dissertation, NorthWest University, Potchefstroom.

\section{KUBHEKA T}

2017. Zuma Education a primary weapon for SA's economic transformation. http://ewn.co.za/2017/01/24/zuma-education-isprimary-weapon-for-sa-s-economic-transformation (accessed on 2 May 2017).

\section{LANDMAN WA}

2011. Sake24: Ethical, responsible leadership is far too rare. Beeld, 4 February:5.

\section{LESSING AC \& DREYER J}

2007. Every teacher's dream: Discipline is no longer a problem in South African Schools! Perspectives on learner conduct. Potchefstroom: The Platinum Press.

\section{LIWANE N}

2017. Quality education and professionalism in South African public education - an Education Law perspective. Unpublished PhD thesis, North-West University, Potchefstroom.

\section{MAHLASE M}

2018 ANC North West PEC disbanded, Supra Mahumapelo removed as provincial chair. Mail \& Guardian https://mg.co.za/article/2018-08- 
31-anc-north-west-pec-disbanded-supra-mahumapelo-removed-asprovincial-chair (accessed on 1 October 2018)

\section{MANS CS}

2015. An Education Law perspective on educator misconduct and educator security. Unpublished MEd dissertation. North-Western University, Potchefstroom.

\section{MAREE K}

2016. First steps in research. Pretoria: Van Schaik.

\section{MAROMO J}

2016. Education an apex priority for ANC: Zuma. https://www. iol.co.za/news/politics/education-an-apex-priority-for-anczuma-2010577 (accessed on 21 May 2016).

\section{MASHIYANE L}

2018. Zondo inquiry and corruption charges pose a twin threat against Zuma. Mail \& Guardian https://mg.co.za/article/2018-09-13-zondoinquiry-and-corruption-charges-pose-a-twin-threat-against-zuma (accessed on 14 October 2018).

\section{MASITSA MG}

2007. Discipline and punishment in township schools in South Africa: Unresolved problems. In IJ Oosthuizen et al. (eds) 2007:155-178.

MILES MB, HUBERMAN AM \& SALDANA J 2013. Qualitative data analysis. Thousand Oaks, CA: Sage.

OOSTHUIZEN IJ (ED.) 2009. Aspects of Education Law. $4^{\text {th }}$ edition. Pretoria: Van Schaik.

OOSTHUIZEN IJ, ROSSOUW JP, RUSSO CJ, VAN DER WALT JL \& WOLHUTER CC (EDS)

2007. Conference Proceedings of the International Conference on Learner Discipline. Potchefstroom: The Platinum Press.

\section{PRESIDENCY, THE}

2013. Remarks by President Jacob Zuma to the UN Secretary General's Global Education First Initiative, High-Level Roundtable, UN Headquarters, New York, USA. http://www.thepresidency. gov.za/speeches/remarks-president-jacob-zuma-un-secretarygeneral $\% E 2 \% 80 \% 99$ s-global-education-first-initiative $\% 2 \mathrm{C}$-high (accessed on 24 August 2017).

\section{ROSSOUW JP}

2010. Labour relations in education: $A$ South African perspective. $2^{\text {nd }}$ edition. Pretoria: Van Schaik.

\section{ROSSOUW MC}

2011. ' $n$ Arbeidsregtelike perspektief op die werksvervulling van die Graad R-opvoeder. Unpublished MEd dissertation, North-West University, Potchefstroom. 
2014. The role of law and policy in the professional security of grade R educators. Unpublished PhD thesis, North-West University, Potchefstroom.

RUSSO CJ \& STEWART DJ

2001. The place of Education Law in the international community. Education Law Journal :18-25. http://eprints.qut.edu.au/23246/ (accessed on 12 March 2013).

\section{RUTHERFORD RM}

2009. A creativity development model to enhance educator security - a labour law perspective. Unpublished PhD thesis, North-West University, Potchefstroom.

\section{SANDELOWSKI M \& BAROSSO J}

2007. Handbook for synthesizing qualitative research. New York: Springer.

\section{SPAULL N}

2017. The unfolding reading crisis: The new PIRLS 2016 results. https://nicspaull.com/2017/12/05/the-unfolding-reading-crisis-thenew-pirls-2016-results (accessed on 17 February 2018).

\section{THOMAS $\mathrm{J} \&$ HARDEN A}

2008. Methods for the thematic synthesis of qualitative research in systematic reviews. BMC Medical Research Methodology 8(1):1-10. https://doi.org/10.1186/1471-2288-8-45

THORNE S, JENSEN L, KEARNEY MH, NOBLIT G \& SANDELOWSKI M 2004 Qualitative meta-synthesis: Reflections on methodological orientation and ideological agenda. Qualitative Health Research 14(10):1342-1365. https://doi.org/10.1177/1049732304269888

\section{TIMULAK L}

2009. Meta-analysis of qualitative studies: A tool for reviewing qualitative research findings in psychotherapy. Psychotherapy Research 19(4-5):591-600. https://doi.org/10.1080/10503300802477989

\section{VAN DER RHEEDE C}

2010. Die Hoërskool Ermelo-hofbeslissing is 'n dubbelsnydende swaard. http://www.litnet.co.za/cgi-bin/giga.cgi?cmd=cause_dir_ news_item\&cause_id=1270 \&news_id=82939\&cat_id=214 (accessed on 30 March 2011).

\section{VAN JAARSVELD SR \& VAN ECK BPS} 1994. Kompendium van die Suid-Afrikaanse arbeidsreg. Johannesburg: Lex Patria.

\section{VAN STADEN LJ}

2006. Billike arbeidspraktyk vir opvoeders in die Suid-Afrikaanse openbare skole. Unpublished MEd dissertation, North-West University, Potchefstroom. 
Journal for Juridical Science (Special Issue) 2018:43(2)

WALSH D \& DOWNE S

2004. Meta-synthesis method for qualitative research: A literature review. Methodological Issues in Nursing Research 50(2):204-211.

WOLHUTER CC \& VAN STADEN JG

2007. Corporal punishment in schools: An historico-educational perspective. In IJ Oosthuizen et al. (eds) 2007:374-393. 


\section{Author Guidelines}

1. Manuscripts must, on receipt thereof by the Editor, be in accordance with the editorial and house style requirements, as stipulated below. Manuscripts not in accordance with this (whether partly or wholly) will not be considered for evaluation. The manuscript must truly contribute to the relevant field, as well as provide coherent, clear and well-researched argumentation/analysis. This applies to both articles and notes (chronicles and case notes).

2. Once the Editor is satisfied that the manuscript meets the editorial and house style requirements, the manuscript will be sent for evaluation to two experts in the field so as to determine whether it is publishable. Upon agreement by an expert to evaluate a manuscript a period of approximately 7 weeks is allowed for such a determination to be made. However, an evaluator may be granted an extended period if convincingly motivated and on condition that such an extension comprises a reasonable period. Manuscripts are presented anonymously to evaluators and the evaluators remain anonymous as well.

3. A page fee of R50-00 per page will be charged for all manuscripts accepted for publication.

4. A manuscript submitted to the JJS must be accompanied by the following declarations by the author(s), namely: (i) Approval that the manuscript was not published in any journal and, if accepted for publication in the JJS, will not be published in any journal other than the JJS; (ii) That the manuscript has been properly text-edited and fully complies with the house style of the JJS; (iii) That the manuscript is entirely original and includes no borrowings from other published works that could cause the JJS or any other party legal liability of any kind; and (iv) Acceptance of the payment of page fees of R50-00 per page if the manuscript is accepted for publication.

5. Manuscripts may be submitted in English or Afrikaans. The desired length for articles is $9000-11000$ words (including footnotes). For notes (chronicles and case notes), the desired length is $6000-8000$ words (including footnotes). Authors must use UK spelling.

6. An electronic version must be submitted to the Editor at: defreitas@ufs.ac.za or jjs@ufs.ac.za

7. Supply suitable headings and subtitles where necessary. Number sections and subsections by means of Arabic figures for example: 3. is followed by 3.1 and 3.1.1.

8. Footnotes below the main text of each page must read as follows:

(1) Coetzee \& Brink 1986:234-245.

(2) Ngwena et al 1987:15. 
(3) Standard Bank v Neugarten 19873 SA 695 W:703.

(4) Standard Bank v Neugarten:706. (Note that this also applies to where a case has been referred to already such as in the preceding example)

(5) Close Corporations Act 69/186:sec. 55(3)(6).

(6) Close Corporations Act:sec. 56.

(7) GK 162 Government Gazette 1974:103(4157).

(8) GK 162/1974:reg. 3.

(9) Where there is a reference to a paragraph, the following applies: National Director of Public Prosecutions and Others v Freedom under Law 20144 SA 298 (SCA):par. 33. Where more than one paragraph is referred to, the following applies: paras. 27-30.

(10) Internet sources must read as follows: Anderson "The meaning of natural law", 22 http://www.da.org.za/2015/05/da-wins-courtcase-for-live-sabc-coverage-of-congress (accessed on 12 August 2015).

(11) Note that when a source reference is referred to more than once, the above style should be maintained and therefore no use of "ibid".

9. Bibliography

Only books, chapters in books, articles, theses and internet sources must be included in the bibliography (by implication, therefore, cases and legislation are excluded). A complete bibliography must be provided, giving all relevant details. List all sources alphabetically according to the surnames of the authors and refrain from creating a separate section for books, articles and internet sources. The following format should be followed:

\section{COETZEE JS \& BRINK KL}

1977. Inflation in South Africa. Acta Economica 27(3):17-36. (Note that "27" denotes the volume number; "(3)" denotes the issue number and "17-36" denotes the first and last page numbers of the article.)

JOHNSON HJ

1977. The effect of legal policy. American Law Review 36(2):23-42.

(Note that the journal's name should be written in full.)

VAN RENSBURG CD (ed.)

1986. Human rights in South Africa/Menseregte in Suid-Afrika. 2nd edition 2de uitg. Pretoria: HAUM.

\section{VOET J}

1698-1704. Commentarius ad Pandectas. Vol 1. Den Haag: De Hondt. 


\section{WATSON AB}

2015. New jurisprudential perspectives on partnerships. http://www. da.org.za/2015/05/da-wins-court-case-for-live-sabc- coverage-ofcongress (accessed on 12 August 2015).

Several entries under the same author: List from older to more recent date. For example:

\section{DE KLERK W}

2006. University law clinics in South Africa. South African Law Journal 122(4):929-950.

2007. Unity in adversity: Reflections on the clinical movement in South Africa. International Journal of Clinical Legal Education December 2007 12(2):95-104.

A separate entry is required for an author mentioned under another author for example:

\section{MCKENDRICK B \& HOFFMAN W (eds.)}

1990. People and violence in South Africa. Cape Town: Oxford University Press.

\section{SANDLER HS \& SEPEL NL}

1990. Violence against children: Sexual abuse. In B McKendrick and W Hoffman (eds.) 1990:225-250.

Journal names must be written out in full.

10. Stereotyped Latin terms such as per se, inter alia, et al must be italicized.

11. Full relevant details of the author and, if applicable, the origin of the article (for example: a paper at a congress) must be provided for example: Anthony Anderson, Associate Professor, Department of Public Law, University of Notre Dame.

12. An abstract of approximately $300-400$ words in English must be included.

13. A possessive tense ending in "s" receives an " 's" for example: Jones's and not Jones'.

14. Numbers are not written out in full for example: "Children under 16 years of age may not partake in any gambling activity".

Not: "Children under sixteen years of age may not partake in any gambling activity".

15. References to "section(s)" or "article(s)" in legislation or any other formal legal document must be abbreviated as follows: sec. 3 (for pural: secs. 5-6) and art. 4 (for plural: arts. 5-6).

16. Regarding dates and percentages the following as examples: 20 March 2014; 30 per cent (not $30 \%$ or thirty percent).

17. When referring to a footnote, the following abbreviation must be used: $f$.

18. Use single spacing between sentences.

19. References to Acts: Child Act 56 of 2003. 